\title{
Measuring Improvement in Quality of Life in Community-Based Development Projects in Nigeria
}

\author{
Muhammad Zayyanu, Zungwenen U. J., Johar F., Rafee M. Majid \\ Faculty of Built Environment, \\ Universiti Teknologi Malaysia, Malaysia \\ zmuhammed1140@gmail.com
}

\begin{abstract}
The lingering problem of poverty prompted many countries to adopt community-based strategies for improving Quality of Life (QoL) of poor communities. Numerous studies have focused on identifying but ignored to establish the contribution of the factors that influence improvement in QoL by communitybased projects. This paper measures, using Structural Equation Modelling, the contribution of the factors that influence QoL in a Community-based Poverty Reduction Project (CPRP) in Nigeria. The model revealed that the measured factors contributed only $36 \%$ of the reduction in poverty, which implies that there are other "hidden" factors responsible for the improvement in the quality of life.

Keywords: Quality of Life, Community-based Projects, Poverty Reduction, Structural Equation Modelling

eISSN 2398-4279 @ 2018. The Authors. Published for AMER ABRA cE-Bs by e-International Publishing House, Ltd., UK. This is an open access article under the CC BY-NC-ND license (http://creativecommons.org/licenses/bync-nd/4.0/). Peer-review under responsibility of AMER (Association of Malaysian Environment-Behaviour Researchers), ABRA (Association of Behavioural Researchers on Asians) and cE-Bs (Centre for EnvironmentBehaviour Studies), Faculty of Architecture, Planning \& Surveying, Universiti Teknologi MARA, Malaysia.

https://doi.org/10.21834/ajqol.v3i11.124
\end{abstract}




\subsection{Introduction}

The concept of Quality of life (QoL) relates to prosperity and general welfare of individuals (Abdul Karim 2012; Aklanoğlu \& Erdoğan 2012; Hanifah \& Hashim 2012; Mohit 2013b). Many development experts favored and argued that the adoption of QoL approach for community development would help local communities to improve their quality of life. As supported by Hamdan et al. (2014), the community-based strategy can enhance societal well-being and quality of life.

Many countries adopted community-based strategies to reduce the number of people with an income of less than $\$ 1$ a day (Chamhuri et al. 2012). Following an agreement between Nigeria and the World Bank, the federal government implemented a Communitybased development program as a strategy for Poverty reduction in Nigeria. The program established the Kebbi-state Community-based Poverty Reduction Project (CPRP) in 2001 which emphasizes the involvement of poor communities in the planning, execution, and management of community-level projects. The target of the project is to reduce poverty of poor communities which will, in turn, improve their quality of life.

This paper aims to measure the contribution of the factors that influence improvement in the quality of life with particular reference to the Kebbi-state Community-based Poverty Reduction Project in Nigeria. Using a conceptual framework for measurement of QoL and Poverty reduction developed from literature review, the paper measured the contribution of factors of participation in the CPRP in Nigeria. The findings of the study will broaden the understanding of the various factors that influence improvement in QoL of community-based development projects in Nigeria.

\subsection{Literature Review}

The quality of life can be measured using both objective and subjective parameters (Mohit 2013a; Ana-Maria 2015). Various authors employed different approaches for measurement of QoL as there is no single universally accepted method for its measurement (Rybakovas 2014). For instance, while Marans (2003) and McCrea et al. (2006) favored an objective approach that is not influenced by subjective opinion, Veenhoven (2000) argues that QoL should be measure based on individual perceptions. While the objective method assesses the actual circumstances of people, the subjective approach is more concerned with individual's satisfaction and feelings about QoL (Muslim et al. 2013). The objective approach measures what people consider being essential to societal well-being, while the subjective measures are more concerned with feelings, experiences, and behavior pattern of individuals (Mohit 2013a).

Numerous authors employed either the subjective or objective approaches to assess QoL. For instance, using subjective parameters, Noor \& Abdullah (2012) investigated Quality of Work Life (QOWL) in multinational firms in Malaysia. Latif et al. (2013) examined the influence of situational factors (subjective) of QoL on recycling behavior in Malaysia. Using objective approach, Mohit (2013a) studied regional variations in the QoL in Malaysia. Despite many studies on the measurement of both subjective and objective quality of life, there is a dearth of studies that empirically test the link between subjective (reflective) satisfaction with 
the objective improvement (formative) in QoL (McCrea et al. 2011).

A comprehensive evaluation of the QoL must assess both objective and subjective parameters (Michalos 2008) to allow the weakness of one approach to be complemented by the strength of the other (Mohit 2013b). Based on the ideas of Michalos (2008) and Mohit (2013b), Rybakovas (2014) expressed the opinion that the overall perceived QoL by individuals consists of a set of latent (hidden) variables which are dependent on the measurable variables (objective QoL). Similarly, Maggino \& Zumbo (2012) opined that the empirically observable subjective indicators tend to reflect on latent (objective) variables, which are not open to people's perception and experience.

\subsection{Conceptualization and Measurement of Poverty}

There is no universally accepted criteria for measuring poverty. Waheed (2012) identified various approaches for the measurement of poverty. The approaches are poverty gap income shortfall, composite poverty measures, the physical quality of life index (PQOLI), the augmented physical quality of life index (APQLI) and the human development index (HDI). However, the approaches to measuring poverty have undergone refinement, which leads to the introduction of the Multidimensional Poverty Index (MPI) as an improvement over the previous methods. The MPI has multiple indicators for measuring the multidimensional aspects of poverty and deprivation with regards to the development of individuals, households, and nations (Chamhuri et al. 2012). The multifaceted nature of the MIP identifies the poor and estimates the extent of poverty of individuals at the household level. It is assessed using indicators that are consistent with the three dimensions of the UNDP Human Development Index of Education, Health and Standard of living.

\subsection{Indicators for Measuring Community Participation and Poverty Reduction}

Many studies have adopted various parameters for measuring community involvement and poverty alleviation. While community involvement is measured using 'participation in community development' (PCD), 'empowerment' (EMP) and 'social capital' (SOC), poverty reduction (PVR), is measured using indicators developed by Oxford Poverty and Human Development Initiative (University of Oxford 2010) (Table 1).

Table 1: Constructs and measures for measuring participation and poverty reduction

\begin{tabular}{|c|c|c|}
\hline Constructs & Variables & Source \\
\hline $\begin{array}{l}\text { Participation in Community } \\
\text { Development (PCD) }\end{array}$ & $\begin{array}{l}\text { Membership of Community Organization, } \\
\text { Implementation of Projects } \\
\text { Contribute Finance } \\
\text { Provide Materials } \\
\text { Provide Labour }\end{array}$ & $\begin{array}{l}\text { Narayan, (1995), CAG } \\
\text { Consultants, (2009); Glass, } \\
(1979)\end{array}$ \\
\hline Empowerment (EMP) & $\begin{array}{l}\text { Awareness of Project } \\
\text { Involvement in Community Meetings } \\
\text { Contribute to Decision Making } \\
\text { Supervision of Project }\end{array}$ & $\begin{array}{l}\text { Braathen, (2000); Narayan- } \\
\text { Parker, (2002); } \\
\text { Samah \& Aref, (2009) }\end{array}$ \\
\hline
\end{tabular}




\begin{tabular}{|c|c|c|}
\hline & Project Maintenance & \\
\hline \multirow[t]{4}{*}{ Social Capital (SOC) } & Solidarity and cooperation & \multirow{4}{*}{$\begin{array}{l}\text { Ferragina, Tomlinson, \& Walker, } \\
\text { (2013); Woolcock \& Narayan, } \\
(2000)\end{array}$} \\
\hline & Give/receive community Assistance & \\
\hline & $\begin{array}{l}\text { Enhanced community development } \\
\text { Self-actualization }\end{array}$ & \\
\hline & Mutual trust & \\
\hline \multirow[t]{7}{*}{ Poverty Reduction (PVR) } & Number of visit to health facility & \multirow[t]{7}{*}{ The University of Oxford, (2010) } \\
\hline & Nutrition improved & \\
\hline & Children in primary school & \\
\hline & Children in secondary school & \\
\hline & Improved housing condition & \\
\hline & Access to services & \\
\hline & Asset ownership & \\
\hline
\end{tabular}

- Number of visit to health facility

- Nutrition improved

- Children in primary school

- Children in secondary school

- Improved housing condition

- Access to services

- Ownership of assets

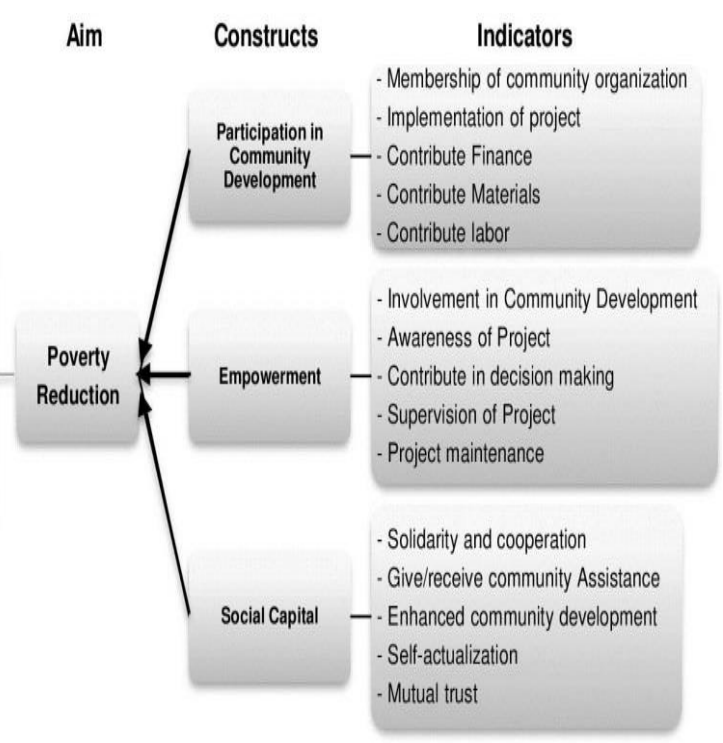

Figure 1: Conceptual framework for measuring poverty reduction

\subsection{Methodology}

From the review of the literature, this paper adopted a conceptual framework for measuring improvement in the living standard of the project beneficiaries. The framework identified three constructs and fifteen variables for measuring community participation and seven indicators for measuring poverty reduction (Fig 1). The adopted variables received recognition by the reviewed literatures as shown in Table 1.

The authors selected, using stratified sampling procedure, two micro-projects from each of the nine infrastructure sectors executed under the CPRP. Twenty households are then 
randomly selected from each community associated with the 18 selected micro-projects. Accordingly, a total of 360 questionnaires were administered using face-to-face delivery. However, availability of functional micro-projects limits the selection of samples for the study. The study contends that the limitation is to allow for measurement of improvement in QoL in communities with operating micro-projects. The data was processed using SPSS and Structural Equation Modelling approach was employed to confirm the model and test the relationships using Amos software version 22.

\subsection{Findings and Discussions}

The Structural equation modeling approach revealed results of the analysis using both measurement and structural models.

Table 2: Exploratory Factor Analysis (EFA)

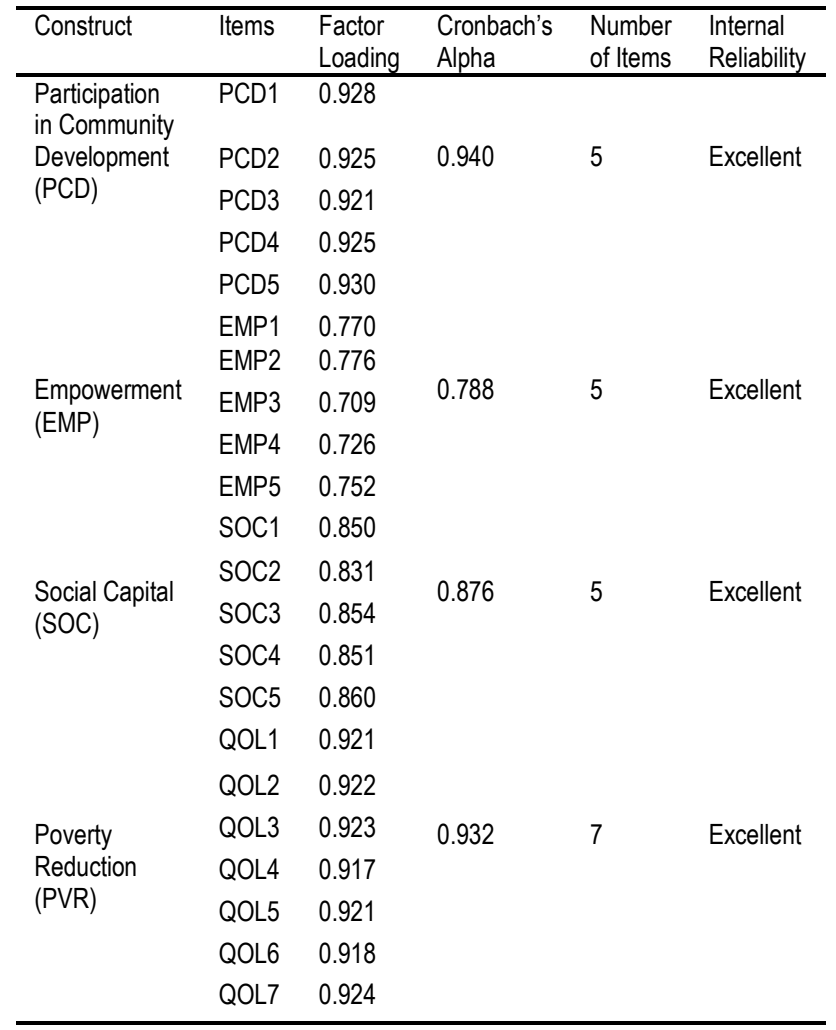

While the measurement sub-model examined the relationship between the observed indicators and their underlying constructs (factors), the structural component explored the contribution of the factors to the improvement in poverty reduction of the CPRP project 
beneficiaries. Exploratory Factor Analysis (EFA) was used to verify the internal reliability and validity of the research questionnaire. All the latent constructs achieve internal reliability with a Cronbach's Alpha of greater than 0.700 (Table 2). The factor loadings of the four constructs (PCD, EMP, SOC, and PVR) shows excellent reliability with all the twenty-two items. Similarly, the analysis shows a Kaiser-Meyer-Olkin (KMO) values of between $80 \%$ and $90 \%$ measure of sampling adequacy which indicate a common variance among the measured variables.

\subsection{The Measurement Model}

Confirmatory Factor Analysis (CFA) is used to assess and validate the measurement model and to test whether the measures of a construct are consistent with the researcher's understanding of that constructs (Awang 2015). Every measurement model involving latent constructs needs to undergo CFA before modeling into SEM. However, due to the problems discovered when computing CFA separately for the individual constructs, Awang (2015) suggested the use of pooled CFA for all latent constructs simultaneously.

In examining validity, three requirements of validity assessment must be achieved to the required level to achieve the model fit and to proceed to the structural model analysis. There are several fit indexes for evaluating the fitness of the SEM models. Table 3 shows the recommended fit indexes and their respective acceptable values. The fit indices in Figure 2 show that apart from the CFI (0.901), the other fitness indexes do not meet the recommended value of acceptance. The option is to delete or correlate the unnecessary items in the model to achieve validity and reliability.

Table 3: Categories of Model Fit and their Level of Acceptance

\begin{tabular}{|c|c|c|c|}
\hline Name of Category & $\begin{array}{l}\text { Name of } \\
\text { Index }\end{array}$ & Index Full Name & $\begin{array}{l}\text { Level of } \\
\text { Acceptance }\end{array}$ \\
\hline \multirow[t]{3}{*}{ Absolute Fit } & Chi-Square & Discrepancy Chi Square & P-value $>0.05$ \\
\hline & RMSEA & $\begin{array}{l}\text { Root Mean Square of Error } \\
\text { Approximation }\end{array}$ & $<0.08$ \\
\hline & GFI & Goodness of Fit Index & $>0.90$ \\
\hline \multirow[t]{4}{*}{ Incremental Fit } & AGFI & Adjusted Goodness of Fit & $>0.90$ \\
\hline & $\mathrm{CFI}$ & Comparative Fit Index & $>0.90$ \\
\hline & TLI & Tucker-Lewis Index & $>0.90$ \\
\hline & NFI & Normed Fit Index & $>0.90$ \\
\hline Parsimonious Fit & $\begin{array}{l}\text { CMIN } \\
\text { (Chisq/df) }\end{array}$ & $\begin{array}{l}\text { Chi Square/Degree of } \\
\text { Freedom }\end{array}$ & $<3.0$ \\
\hline
\end{tabular}




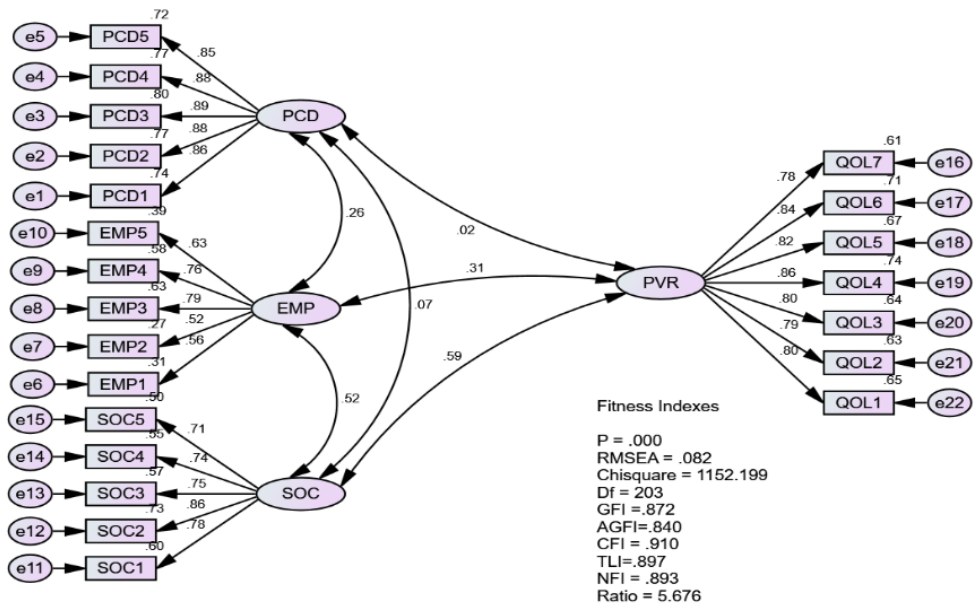

Figure 2: The measurement model

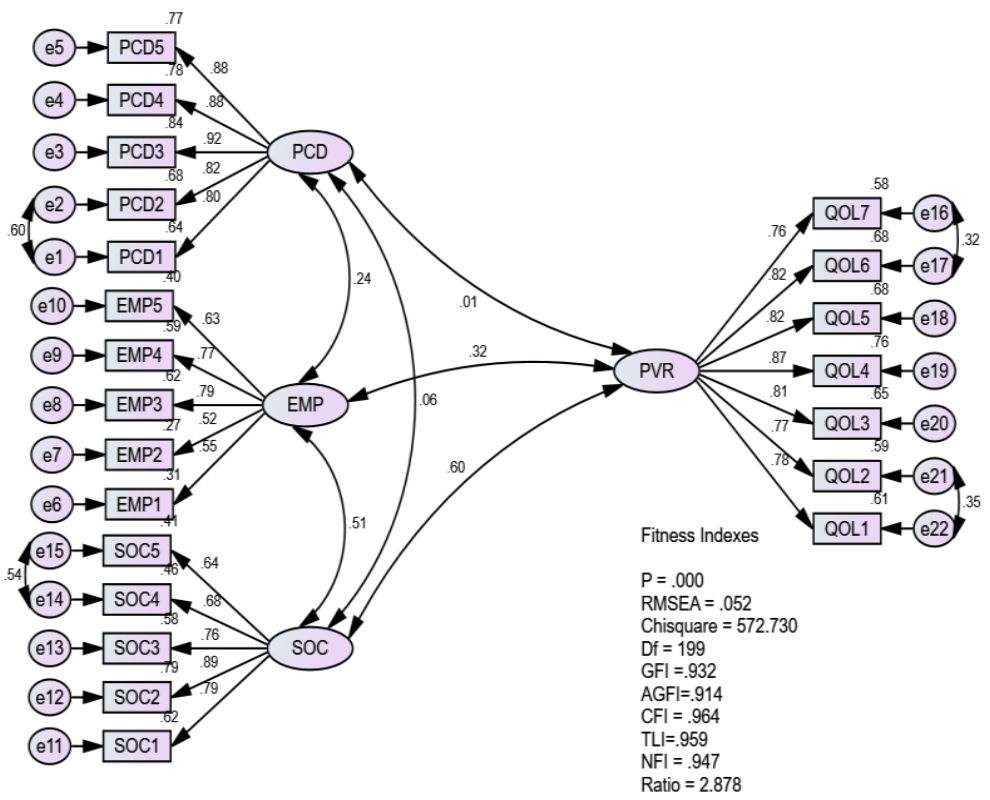

Figure 3: Modified measurement model

The model modification was carried out, and a new specified model was estimated. As expected, correlating the unnecessary items improved the model leading to achievement of 
all the fitness indices in Figure 3. The result of the modified pooled CFA shows a satisfactory fit model that achieved all the fit indexes. The re-specified measurement model meets the requirement of validity and reliability.

\subsection{Assessing the Validity and Reliability of the Measurement Model}

The factor loadings of the model shown in Table 4 are adequate and the model achieved both "convergent" and "construct" validity as both the Composite Reliability (CR) and the Average Variance Extracted (AVE) are above 0.6 and 0.5 respectively. The model also achieved discriminant validity as indicated in Table 5 because the bold and diagonal are greater than the preceding values in their rows and columns.

Table 4: CFA Result for the Construct in the Model

\begin{tabular}{lllll}
\hline Construct & Items & Factor Loading & CR $(\geq 0.6)$ & AVE $(\geq 0.5)$ \\
\hline PCD & PCD1 & 0.80 & & \\
& PCD2 & 0.82 & 0.935 & 0.742 \\
& PCD3 & 0.92 & & \\
& PCD4 & 0.88 & & \\
EMP & PCD5 & 0.88 & & \\
& EMP1 & 0.55 & 0.779 & 0.501 \\
& EMP2 & 0.52 & & \\
& EMP3 & 0.79 & & \\
SOC & EMP4 & 0.77 & & \\
& EMP5 & 0.63 & 0.573 \\
& SOC1 & 0.79 & & \\
& SOC2 & 0.89 & & \\
& SOC3 & 0.76 & & \\
& SOC4 & 0.68 & & \\
& SOC5 & 0.64 & & \\
& QOL1 & 0.78 & & \\
& QOL2 & 0.77 & & \\
& QOL3 & 0.81 & & \\
& QOL4 & 0.87 & & \\
& QOL5 & 0.82 & & \\
& QOL6 & 0.82 & & \\
& QOL7 & 0.86 & & \\
\end{tabular}

Table 5: Summary of Discriminant Validity Index for the Constructs

\begin{tabular}{ccccc}
\hline Construct & PCD & EMP & SOC & PVR \\
\hline PCD & 0.86 & & & \\
EMP & 0.24 & 0.71 & & \\
SOC & 0.06 & 0.51 & 0.76 & \\
PVR & 0.01 & 0.32 & 0.60 & 0.82 \\
& & & & \\
\hline
\end{tabular}

\subsection{Structural Equation Model (SEM)}

In figure 4 the structural path model is presented and evaluated. The model explained $36 \%$ 
of the variance accounted for by the combined influence of the predictors (participation in community development, empowerment, and social capital). This result implies that the combined influence of the variables of community involvement in poverty reduction is $36 \%$ while $64 \%$ does not affect poverty alleviation. However, among the three factors, social capital has a more significant impact (0.59) on the relationship. The influence of social capital on poverty reduction is also buttressed by (Okunamadewa et al. 2005), (Dschang 2009), and (Santini et al. 2012).

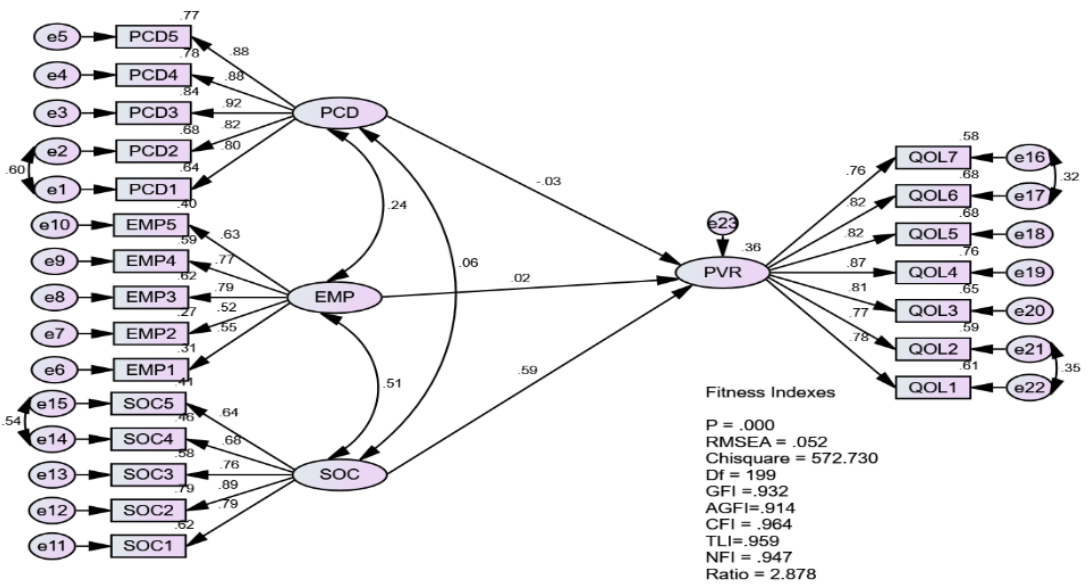

Figure 4. Model predicting poverty reduction

Similarly, only one of the paths $(\mathrm{SOC})$ out of the three linking the independent variables (PCD, EMP, and SOC) to the dependent variable (PVR) is significant at the critical ratio test $(> \pm 1.96$, $p<0.05)$. The probability of getting a critical ratio as large as 11.721 in absolute value is less than 0.001 (Table 6). In other words, the regression weight for SOC in the prediction of PVR is significantly different from zero at the 0.001 level (two-tailed).

Table 6: Regression weights for path estimate

\begin{tabular}{lllll}
\hline Path & Estimate (B) & C.R & P-Value & Result \\
\hline PVR <--- PCD & -0.028 & -0.777 & 0.437 & Not significant \\
PVR<--- EMP & 0.037 & 0.436 & 0.663 & No significant \\
PVR<--- SOC & 0.604 & 11.721 & $* * *$ & Significant \\
\hline
\end{tabular}

Poverty, being a multi-dimensional construct, has multiple cause-effect relationships. The $64 \%$ of the poverty reduction that could not be explained by the model is caused by other "hidden" factors other than those associated with community involvement. Therefore, implies that the lingering problems of poverty in developing countries are so complex that they cannot be solved by a community-based poverty reduction program alone. Investment in both 
physical and social infrastructure is necessary to reduce poverty (Ogun 2010). As observed by Hewett \& Montgomery (2001), the inadequate provision of public services can stalemate efforts to alleviate poverty. For instance, lack of adequate water supply and sanitation can cause elevated health risks to households; and small-scale enterprises requiring electricity face higher production costs.

\subsection{Conclusion}

The paper measured the influence of factors of community participation on poverty reduction towards enhancing the quality of life of the project beneficiaries. The study developed a model of improvement in Quality of Life for a Community-based poverty alleviation project in Nigeria. The finding of the study revealed a complimentary influence of the three dimensions of community involvement (community participation, empowerment, and social capital) in poverty reduction in Kebbi state, Nigeria.

However, the findings of the study indicate that community involvement accounted for only $36 \%$ of the poverty reduction of the project's beneficiaries. The authors, therefore, recommend the adoption of other poverty alleviation strategies that address the multidimensional nature of poverty in developing countries. Such strategies may focus on investigating other pro-poor natural sectors of the economy like agriculture to complement community-based development projects in developing countries. The authors contend that because the majority of poor people used agriculture as their primary source of income, focusing poverty reduction on the sector can tremendously reduce poverty.

\section{References}

Abdul Karim, H., (2012). Low-Cost Housing Environment: Compromising Quality of Life? Procedia - Social and Behavioral Sciences, 35(December 2011), pp.44-53.

Aklanoğlu, F. \& Erdoğan, E., (2012). Improvement Quality of Life for an Anatolian Traditional Settlement: KonyaSille Case. Procedia - Social and Behavioral Sciences, 35(December 2011), pp.420-430.

Ana-Maria, V., (2015). Study on Promoting Quality of Life Through Physical Exercise. Procedia - Social and Behavioral Sciences, 180, pp.1439-1443.

Awang, Z., (2015). SEM Made Simple First., MPWS Rich Publication Sdn. Bhd. (1132290-K).

Braathen, E., (2000). Attacking Poverty. Forum for Development Studies, 27(2), pp.331-350.

CAG Consultants, (2009). Participation : A theoretical context. , (1969), pp.1-13.

Chamhuri, N.H., Karim, H.A. \& Hamdan, H., 2012. Conceptual Framework of Urban Poverty Reduction : A review of literature. Procedia - Social and Behavioral Sciences, 68, pp.804-814.

Dschang, P.O.B., (2009). Does Social Capital determine Poverty ? Evidence from Cameroon Household University of Dschang Faculty of Economics and Management Email : jtabiatem@yahoo.com Does Social Capital determine Poverty? Evidence from Cameroon Household Survey Abstract There i. October, (March). 
Ferragina, E., Tomlinson, M. \& Walker, R., (2013). Poverty, Participation and Choice: The Legacy of Peter Townsend. , (May 2013), pp.1-69.

Glass, J.J., (1979). Citizen participation in planning: the relationship between objectives and techniques. Journal of the American Planning Association. American Planning Association, 45(2), pp.180-189.

Hair, J.F. et al., (2006). Multivariate Data Analysis Sixth., Upper Saddle River, N.J.: Pearson Prentice Hall.

Hanifah, N.A. \& Hashim, R., (2012). The Madrid Protocol 1991 and its Environmental Impacts towards the Quality of Life. Procedia - Social and Behavioral Sciences, 35(December 2011), pp.398-403.

Hewett, P.C. \& Montgomery, M., (2001). Poverty and Public Services in Developing-Country Cities, New York: Population Council.

Maggino, F. \& Zumbo, B.D., (2012). Measuring the quality of life and the construction of social indicators. In K. C. Land, A. C. Michalos, \& M. J. Sirgy, eds. Handbook of social indicators and quality of life research. Springer, pp. 201-238.

Marans, R.W., (2003). Understanding environmental quality through quality of life studies: the 2001 DAS and its use of subjective and objective indicators. Landscape and Urban Planning, 65(1-2), pp.73-83.

McCrea, R., Stimson, R. \& Marans, R.W. (2011)., 2011. The evolution of integrative approaches to the analysis of quality of urban life. In R. J. S. (Eds. . R. W. Marans, ed. Investigating quality of urban life: Theory, methods and empirical research. Springer, pp. 77-106.

McCrea, R., Shyy, T.K. \& Stimson, R., (2006). What is the strength of the link between objective and subjective indicators of urban quality of life? Applied Research in Quality of Life, 1(1), pp.79-96.

Michalos, A.C., (2008). Education, happiness and wellbeing. Social Indicators Research, 87(3), pp.347-366.

Mohit, M.A., 2013a. Objective Analysis of Variation in the Regional Quality of Life in Malaysia and its Policy Implications. Procedia - Social and Behavioral Sciences, 101, pp.454-464.

Mohit, M.A., 2013b. Quality of Life in Natural and Built Environment - An Introductory Analysis. Procedia - Social and Behavioral Sciences, 101, pp.33-43.

Narayan-Parker, D., (2002). Empowerment and Poverty Reduction: A Sourcebook. , p.371.

Narayan, D., 1995. Designing community based development. , (4).

Noor, S.M. \& Abdullah, M.A., (2012). Quality Work Life among Factory Workers in Malaysia. Procedia - Social and Behavioral Sciences, 35(December 2011), pp.739-745.

Ogun, T.P., (2010). Infrastructure and Poverty Reduction: Implications for Urban Development in Nigeria. Working Paper Series.

Okunamadewa, F.Y., Yusuf, S.A. \& Omonona, B.T., (2005). Social Capital and Poverty Reduction in Nigeria. , pp.147.

Rybakovas, E., (2014). Cause-effect Relationships Between Objective and Subjective Measures of Quality of Life in Lithuania Municipalities. Procedia - Social and Behavioral Sciences, 156(April), pp.83-87.

Samah, A.A. \& Aref, F., (2009). People 's Participation in Community Development : A Case Study in a Planned Village Settlement in Malaysia. World Rural Observations, 1(2), pp.45-54. 
Zayyanu, M., et.al. / Asian Journal of Quality of Life (AjQoL), 3(11) May / Jun 2018 (p.81-92)

Santini, I., Pascale, A. De \& La, R.,(2012). Social Capital and Household Poverty : the Case of European Union Social Capital and Household Poverty : the Case of European Union.

University of Oxford, (2010). Oxford Poverty and Human Development Initiative (OPHI) Country Briefing : Ethiopia. (June), pp.1-4.

Veenhoven, R., (2000). The four qualities of life: Ordering Concepts and Measures of the Good Life. Journal of happiness studies, 1, pp.1-39.

Waheed, O.O., (2012). Concept, Measurement and Causes of Poverty: Nigeria in Perspective. American Journal of Economics, 2, pp.25-36.

Woolcock, M. \& Narayan, D., (2000). Social Capital: Implications for Development Theory, and Policy. World Bank Research Observer, 15, No. 2(August), pp.225-249. 